\section{Nauplius}

The Journal OF THE

Brazilian Crustacean Society

e-ISSN 2358-2936

www.scielo.br/nau www.crustacea.org.br

\title{
Decapod abundance and species richness in the bycatch of Xiphopenaeus kroyeri (Heller, 1862) fishery, Santa Catarina, southern Brazil
}

Gilson Stanski (D) orcid.org/0000-0002-4778-7336

Geslaine R. L. Goncalves (D) orcid.org/0000-0001-7443-6913

Raphael C. Grabowski (D)orcid.org/0000-0001-9414-8310

Milena R. Wolf (D) orcid.org/0000-0003-1022-1360

Antonio Leão Castilho (D) orcid.org/0000-0003-0001-9054
1 NEBECC - Group of Studies of Crustacean Biology, Ecology and Culture, Zoology Department, Institute of Biosciences of Botucatu, São Paulo State University (UNESP). Botucatu, São Paulo, Brazil.

ZOOBANK: http://zoobank.org/urn:lsid:zoobank.org:pub:66F3A568-D904-49FEBD91-7F8CAA31617F

\section{Abstract}

We aimed to analyze the crustacean bycatch from the Xiphopenaeus kroyeri fishery in the Santa Catarina State and compare the bycatch's biomass to that of the target species. Shrimp and environmental factors were sampled monthly from July 2010 through June 2011. For each crustacean species, we calculated the number of individuals, the relative abundance and the occurrence frequency. The relative abundance was classified as very abundant $(\mathrm{Va})$, abundant $(\mathrm{Ab})$ or low abundance $(\mathrm{La})$, while the occurrence frequency was labeled continuous (Co), accessory (Ac) or accidental (Ad). We observed a total richness of 28 species, which is considered high for a subtropical region. Brachyura was the most frequent taxon (74\%) followed by Penaeiodea (18\%). Five species were considered Va (Arenaeus cribrarius, Callinectes danae, C. ornatus, Isochelis sawayai and Pleoticus muelleri), and eight species were considered Co (A. cribrarius, C. danae, C. ornatus, Farfantepenaeus paulensis, Hepatus pudibundus, Libinia spinosa, Litopenaeus schmitti and Sicyonia dorsalis), suggesting that the studied environment is heterogeneous and provides a variety of microhabitats, enabling many species to coexist. Therefore, the high species richness observed demonstrates the ecological importance of this region and thus the necessity of strategies aiming to minimize the impacts caused by trawling fisheries.

\section{KeYWORDS}

Babitonga Bay, fisheries impact, biodiversity, trawling, crustacean bycatch 


\section{INTRODUCTION}

Fishing activities generate food, income and jobs and are important for coastal communities (Bail and Branco, 2007). However, overfishing has reduced profitable shrimp stocks (D'Incao et al., 2002), affecting the target species and several others (bycatch) (Pezzuto et al., 2006).

Large amounts of bycatch are captured because of the methods used to capture shrimp (i.e., trawling). This fishing gear exhibits low selectivity (Souza et al., 2017). In this procedure, non-profitable and small (or juvenile) specimens are discarded back into the sea, usually dead. The discarded taxa are quite diverse, including fishes, crustaceans, mollusks, echinoderms and cnidarians (Coelho et al., 1986).

Such a lack of selectivity in this fishing activity may lead to the reduction or even extinction of the local biodiversity. Compromising of key species might lead to biological instability in the ecosystem and a decrease in the subsistence of hundreds of fishermen whose prosperity depends on this activity (Murray et al., 1992).

The seabob shrimp Xiphopenaeus kroyeri (Heller, 1862) fisheries in coastal areas catch a high diversity of bycatch causing considerable damage to the environment (Coelho et al., 1986), as observed in studies on the bycatch fauna of $K$. kroyeri in other regions of Brazil. For example, Rodrigues-Filho et al. (2016) have evaluated the seasonal cycles of the carcinofauna caught in seabob shrimp fishing in northeastern Brazil, Costa and Di Beneditto (2009) and Costa et al. (2016) have studied on the northern coast of Rio de Janeiro. Graça-Lopes et al. (1993a) have analyzed the composition and distribution of decapod crustaceans associated with $K$. kroyeri fishery in São Paulo state, and Graça-Lopes et al. (2002a) and Severino-Rodrigues et al. (2002) in Perequê Beach, São Paulo State. All these studies have reported an expressive richness of the bycatch in relation to the target species.

Therefore, it is essential to create management plans that consider the marine biological community as a whole. This is fundamental for implementing mitigating measures or evaluating the measures that already exist. Currently, the major mitigating measure is a fisheries closure period, in which trawling activities are prohibited from March 1 through May 31 in the southern and southeastern Brazilian coast (Franco et al., 2009).

Furthermore, in order to understand the reasons for the presence or absence of a diversity of organisms in a given area, it is necessary to study and comprehend their interactions with the environment and its resources. Among the environmental components influencing the occurrence and distribution of marine benthic species, the sediment granularity and organic matter content and bottom water salinity and temperature exert great influence on decapod crustaceans (Bertini et al., 2004; Mantelatto et al., 2004; Fantucci et al., 2009).

Therefore, the aim of this study was to describe the species richness and abundance of decapod crustaceans comprising the bycatch from the $X$. kroyeri fishery, the influence of environmental factors on the bycatch, and the monthly proportion of the target species biomass in relation to the bycatch biomass near Babitonga Bay. This bay is located on the northern coast of the state of Santa Catarina, the area has a rich fauna in crustaceans, fishes, birds and aquatic mammals (Rodrigues et al., 1998).

\section{Materials and Methods}

Decapods and environmental factors were sampled monthly from July 2010 through June 2011 in five sampling stations parallel to the coast with depths of 5, 8, 11, 14 and $17 \mathrm{~m}$. All sampling stations were previously established using the Global Positioning System (GPS), in the area adjacent to Babitonga Bay. Babitonga Bay is located in the northern littoral zone off Santa Catarina State (geographical coordinates:

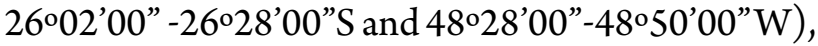
Brazil near the cities of Joinville, Itapoá and São Francisco do Sul (Fig. 1).

Biological samples were collected using trawls with sampling effort of $1 \mathrm{~h}$ (speed: 2 knots) over a total area of $37,000 \mathrm{~m}^{2}$ using a shrimp fishing boat equipped with double-rig nets. After each trawl, nets were brought to the fishery boat, and the animals were sorted, identified and placed in thermal boxes containing crushed ice. The samples were then taken to the laboratory, where we identified them down to species level according to Costa et al. (2003) and Melo (1996, 1999a) and we quantified and weighed $(\mathrm{g}$ ) each species (Grabowski et al., 2014). 


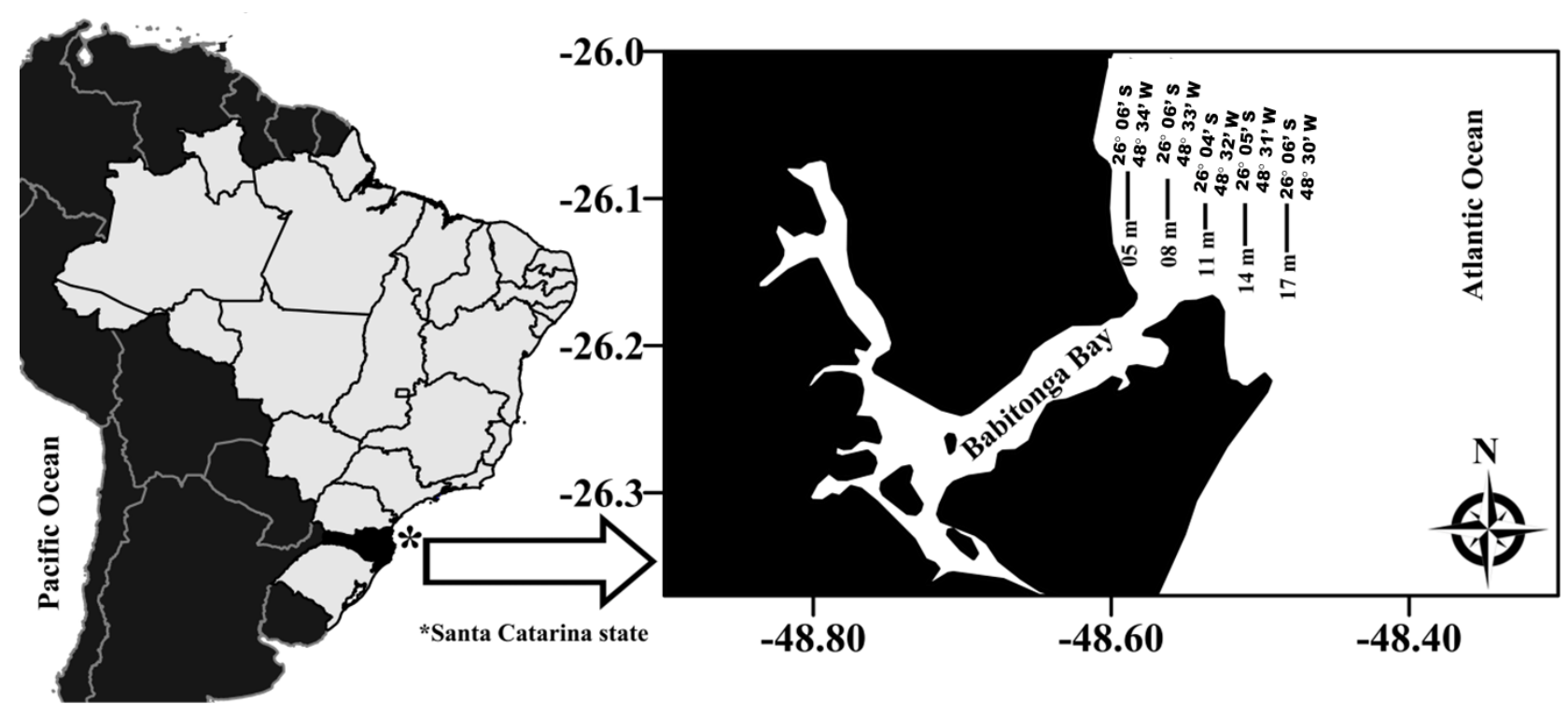

Figure 1. Studied region. The adjacent area from the Babitonga Bay, northern litoral of the Santa Catarina State, highlighting the sampled depths (source: Grabowski et al., 2014).

\section{Environmental factors}

We used a Van Dorn bottle to obtain bottom water samples in each sampling station, and we measured its temperature and salinity using a mercury thermometer (to the nearest $0.1^{\circ} \mathrm{C}$ ) and an optical refractometer (to the nearest $0.1 \mathrm{psu}$ ), respectively.

Sediment samples were collected quarterly, specifically once in each season (e.g., summer: January to March). The methodology adopted in the subsequent analysis was based on previous studies (Håkanson and Jansson, 1988; Tucker, 1988).

The sediment was obtained using a Peterson grab at each of the five sampling stations and frozen until laboratory analysis. In the laboratory, samples were dried in an oven at $70^{\circ} \mathrm{C}$ for $72 \mathrm{~h}$. Subsequently, $10 \mathrm{~g}$ subsamples were placed in porcelain containers and weighed before drying in a muffle furnace at $500^{\circ} \mathrm{C}$ for $3 \mathrm{~h}$ in order to burn off all the organic matter content. Subsequently, samples were weighed again, and the difference between the initial and final weights was considered the amount of organic matter associated with the substrate.

Other $100 \mathrm{~g}$ subsamples were treated for $10 \mathrm{~min}$ in $250 \mathrm{ml}$ of a $0.2 \mathrm{~N}$ solution of $\mathrm{NaOH}$ in distilled water to ease the separation of silt and clay from larger grains. Next, subsamples were rinsed through a $0.0625 \mathrm{~mm}$ sieve in order to eliminate silt and clay. After that study, subsamples were again dried in an oven at $60^{\circ} \mathrm{C}$ for
$24 \mathrm{~h}$ and then sieved through a sequence of six sieves. As a result, sediment was classified in the following granulometric classes: gravel $(>2 \mathrm{~mm})$, very coarse sand $(1-2 \mathrm{~mm})$, coarse sand $(0.5-1 \mathrm{~mm})$, medium sand $(0.25-0.5 \mathrm{~mm})$, fine sand $(0.125-0.25 \mathrm{~mm})$ and very fine sand $(0.0625-0.125 \mathrm{~mm})$.

The grain size was then expressed on the phi scale $(\Phi)$, which corresponds to the measurement of the central tendency for sediment samples (Suguio, 1973). The most frequently found granulometric fraction in the sediment sample was determined by cumulative curves using the formula: $M=\Phi_{16}+\Phi_{50}+\Phi_{84 / 3}$. The phi classes were converted into granulometric fractions using $\log _{2}$, resulting in the following: $-1=\Phi<0$ (gravel), $0=\Phi<1$ (coarse sand), $1=\Phi<2$ (medium sand), 2 $=\Phi<3$ (fine sand), $3=\Phi<4$ (very fine sand) and $\Phi$ $\geq 4$ (silt + clay).

\section{Bycatch analysis}

For each crustacean species, we calculated the total number of individuals and the seasonal abundance. The relative abundance (RA) of each species was calculated as the number of that species divided by the total number of captured individuals (excluding the target species, X. kroyeri) (Costa et al., 2016).

The Catch Per Unit Effort (CPUE) was used to express the number of individuals captured in each hour of trawling (ind. $\mathrm{h}^{-1}$ ). The abundance of each 
species was classified according to Graça-Lopes et al. (1993b) as follows: very abundant (Va) (> 5\% of the total amount captured), abundant (Ab) (1-5\%), and low abundance (La) $(<1 \%)$. We also observed the occurrence frequency of each species, classifying them in three categories: Continuous (Co) (present in $>$ $50 \%$ of samples), Accessory (Ac) (present in 25-50\% of samples) and Accidental (Ad) (present in < 25\% of samples) (Dajoz, 1983).

A redundancy analysis (RDA) was used to test the relationship between the species (considering only those found in at least $10 \%$ of the samples) and environmental factors. The set of environmental variables used in the RDA analysis included bottom water salinity and temperature, and sediment granularity and associated organic matter content. The routine Vegan was used in the software R (R Development Core Team, 2009). Data were log-transformed prior to analysis (Zar, 1999).

Kruskal-Wallis and Dunn post hoc tests were used to analyze the temperature variation by seasons $(\alpha=0.05)$. The ratio for each month was calculated as the quotient between the number of $X$. kroyeri and carcinofauna bycatch. Deviations were tested using the binomial test $(\alpha=0.05)$ (Wilson and Hardy, 2002).
Results

Composition of the catch

We caught 85,198 individuals, among which the target species $X$. kroyeri was the most abundant, corresponding to $89 \%$ of all individuals. The crustacean bycatch was composed of 13 families, 20 genera and 28 species, totaling 9,286 individuals (Tab. 1), among which brachyurans predominated $(73.53 \%)$, followed by penaeids (18.23\%), anomurans (7.0\%) and carideans (1.28\%) (Fig. 2). By family, Portunidae was most abundant (69\%), followed by Solenoceridae (9\%) and Penaeidae (6\%) (Tab. 1).

Callinectes danae and Pleoticus muelleri were more abundant during winter, and C. ornatus, I. sawayai and A. cribrarius were more abundant during summer. These were also the most abundant species in this study, classified as Va. We classified 11 species as $\mathrm{Ab}$ (A. longinaris, F. paulensis, L. schmitti, R. constrictus, S. dorsalis, L. loxochelis, H. pudibundus, L. spinosa, $L$. ferreirae, L. mediterranea and E. oplophoroides), while 12 species were considered La (Tab. I).

Eight species were considered Co (L. schmitti, F. paulensis, S. dorsalis, C. danae, A. cribrarius, C. ornatus, L. spinosa and H. pudibundus), five were considered Ac

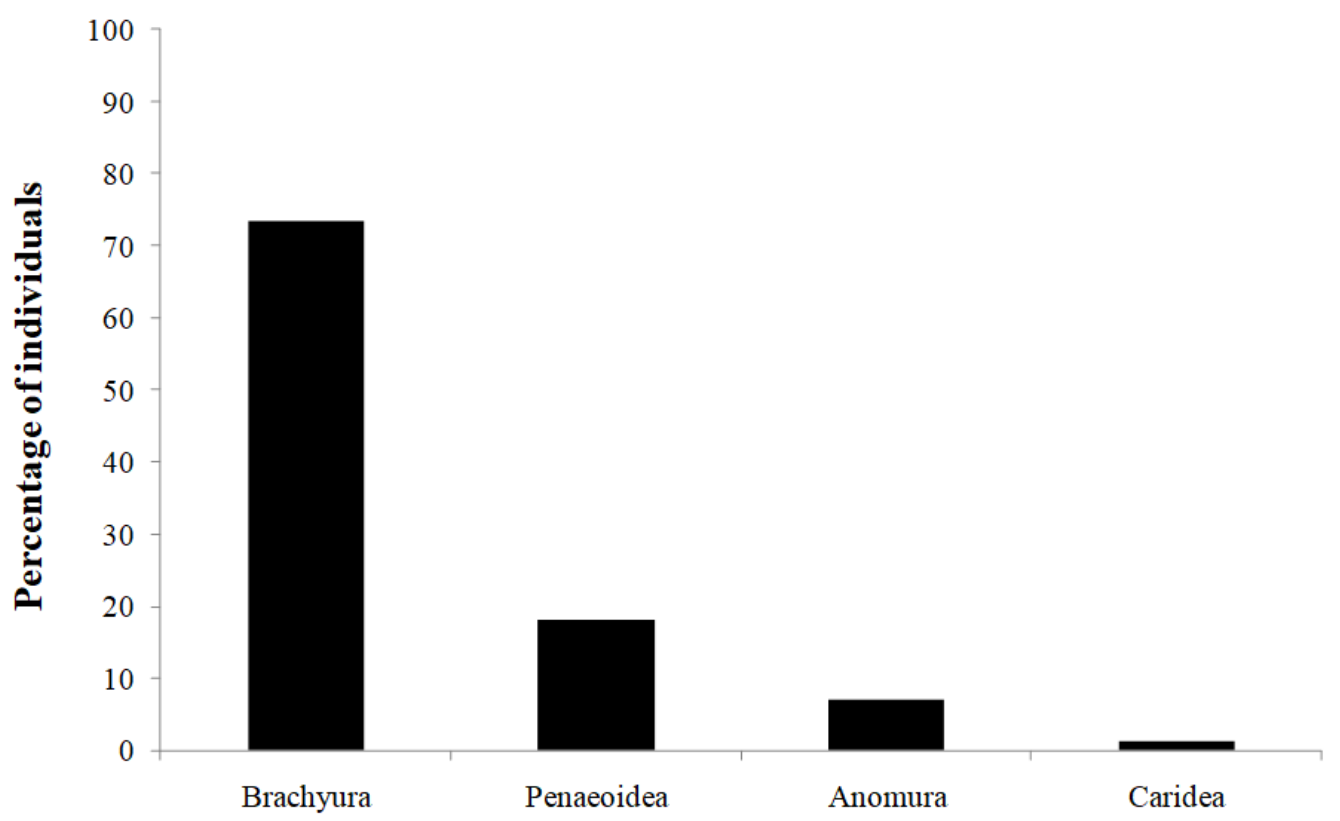

Taxonomic Category

Figure 2. Relative composition (\%) of individuals comprised in the carcino-bycatch, sorted by different taxonomic categories, from the artisanal Xiphopenaeus kroyeri fishery. Samples were taken from July 2010 through June 2011 in the adjacent area from the Babitonga Bay, Santa Catarina State, Brazil. 
Table 1. Seasonal (n), total (n) and relative abundance (AR), and occurrence frequency (FO) of the crustaceans decapods species captured along with the Xiphopenaeus kroyeri fishery in the northern littoral of the Santa Catarina State, from July 2010 through June 2011. Win: winter; Spr: spring; Sum: summer; Aut: autumn; Categ: category; Va: very abundant; Ab: abundant; La: little abundant; Co: constant; Ac: accessory; Ad: Accidental.

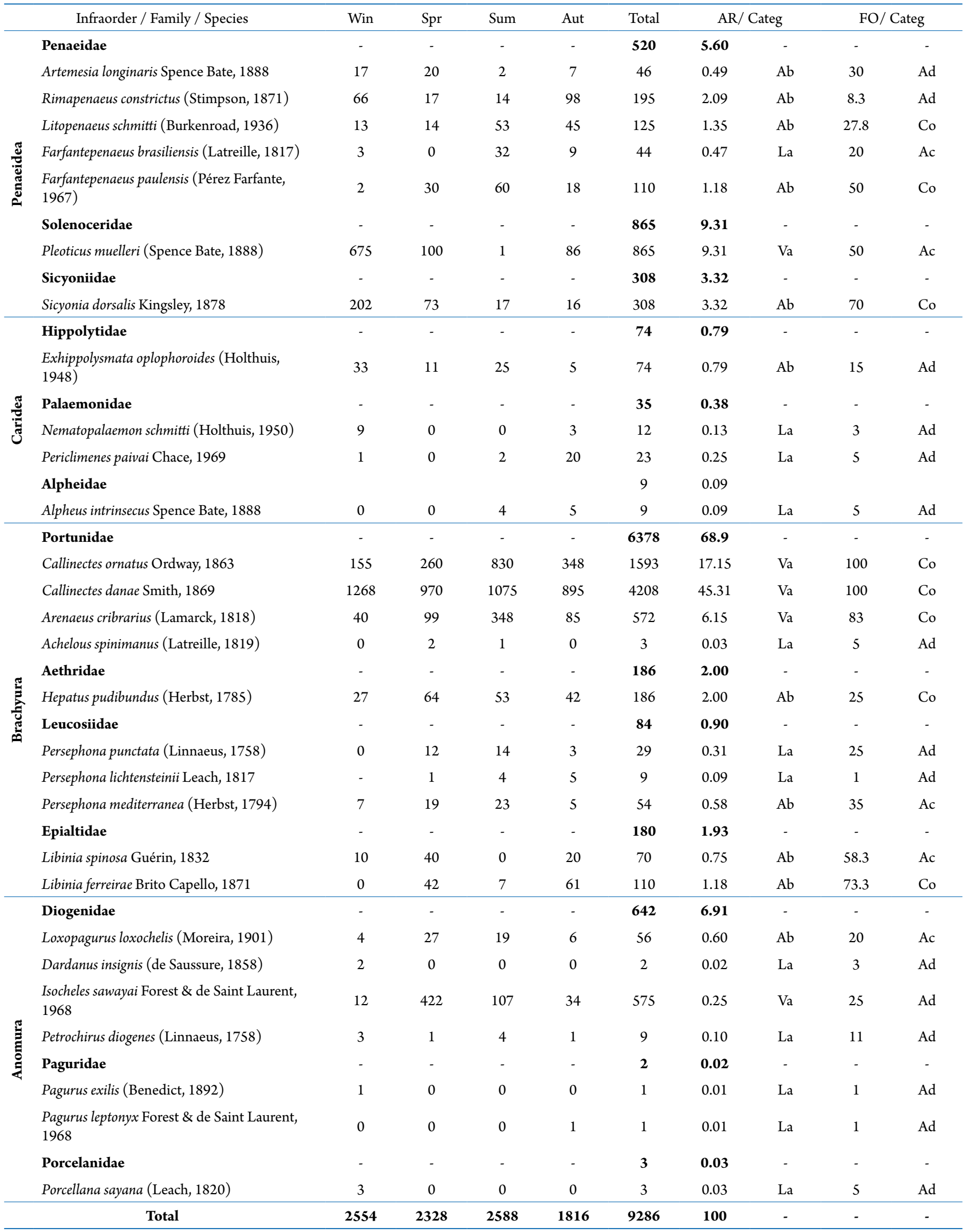


(P. mediterranea, L. loxochelis, P. muelleri, R. constrictus and F. brasiliensis), and the other 15 were considered Ad (Tab. 1).

For each captured crustacean bycatch kilogram, we obtained an average of $8.2 \mathrm{~kg}$ of $X$. kroyeri (bycatch proportion: 0.125 ). However, in November, December and February (warmer water months), the bycatch proportion was closer to 0.5 (binomial test, $\mathrm{p}<0.05$ ) (Fig. 3).
Among the Penaeoidea, $P$. muelleri was the most abundant captured species (71\%), followed by $L$. schmitti (11\%), F. brasiliensis (10\%), F. paulensis (4\%) and $A$. longinaris (4\%).

Temperature differed among seasons, with cold water temperatures during the winter, and warmer temperatures during the summer (Kruskal-Wallis with post hoc Dunn test, p < 0.05) (Fig. 4), also had the greatest relationship with the catch composition and was

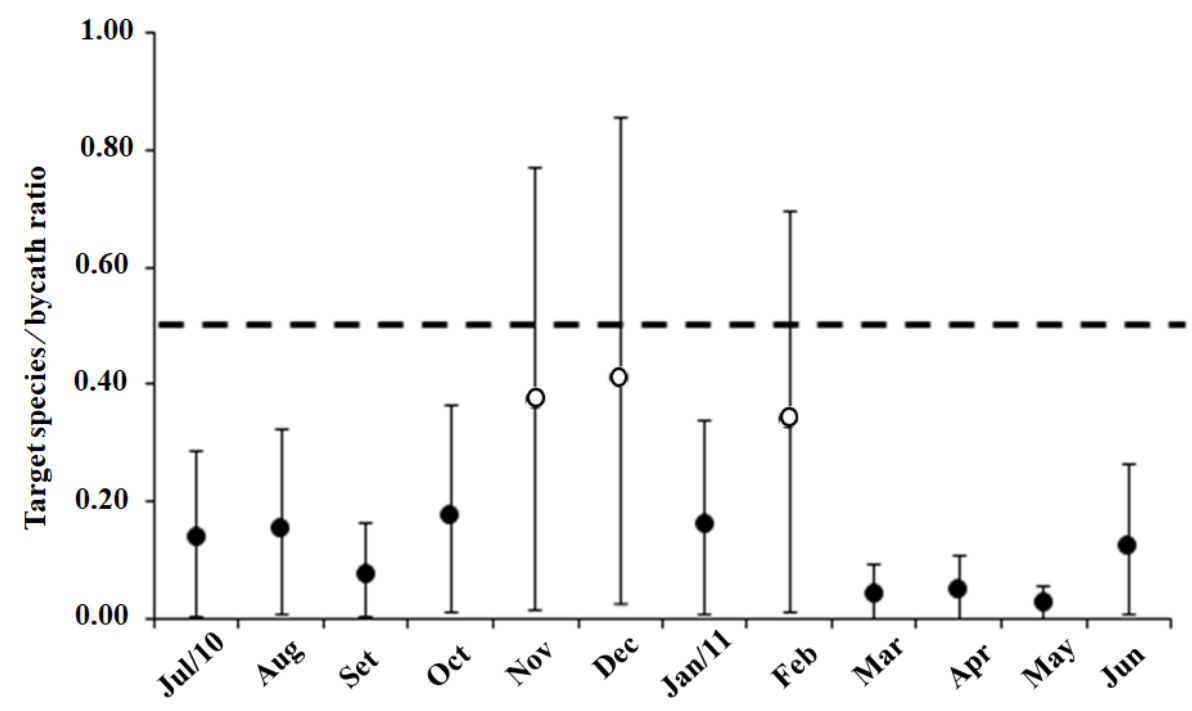

Figure 3. Quotient between the carcino-bycatch and Xiphopenaeus kroyeri abundance. Samples were taken from July 2010 through June 2011 in the adjacent area from the Babitonga Bay, Santa Catarina State, Brazil. Black circles indicate deviations from a 1:1 expected proportion (Binomial test, $p<0.05$ ).

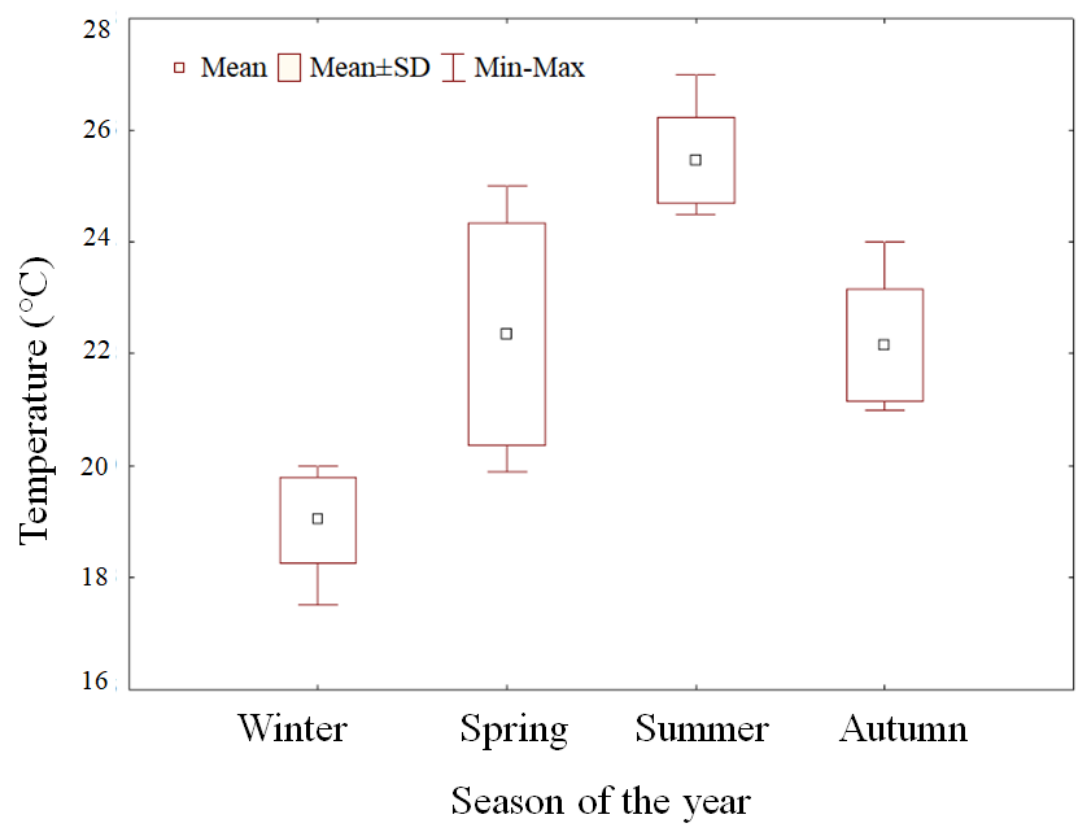

Figure 4. Temperature variation along the seasons of the year. Samples were taken from July 2010 through June 2011, in the adjacent area from the Babitonga Bay, Santa Catarina State, Brazil. 
negatively correlated with the presence of $P$. muelleriand A. longinaris, and positively correlated with F. paulensis and A. cribrarius. We observed a positive correlation between salinity and the abundance of I. sawayai, and a negative correlation with $R$. constrictus. Phi values were positively correlated with the abundance of $C$. ornatus and negatively correlated with the abundance of $R$. constrictus (RDA, $p<0.05$; Fig. 5, Tab. 2).

Table 2. Summary of the results from the Redundancy Analysis (RDA) between species and environmental factors. Samples were taken from July 2010 through June 2011 in the adjacent area from the Babitonga Bay, Santa Catarina State, Brazil. Significance was

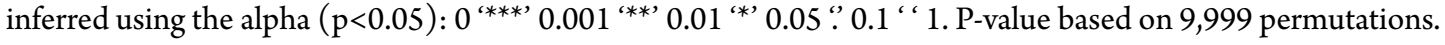

\begin{tabular}{lccc}
\hline Environmental factors & RDA1 & RDA2 & r2 \\
\hline Organic matter content & -0.47495 & -0.88001 & 0.0505 \\
Temperature & 0.99925 & -0.03874 & 0.2283 \\
Salinity & 0.14592 & 0.98930 & $0.5711^{* *}$ \\
Phi & -0.75648 & -0.65401 & 0.3115 \\
\hline
\end{tabular}

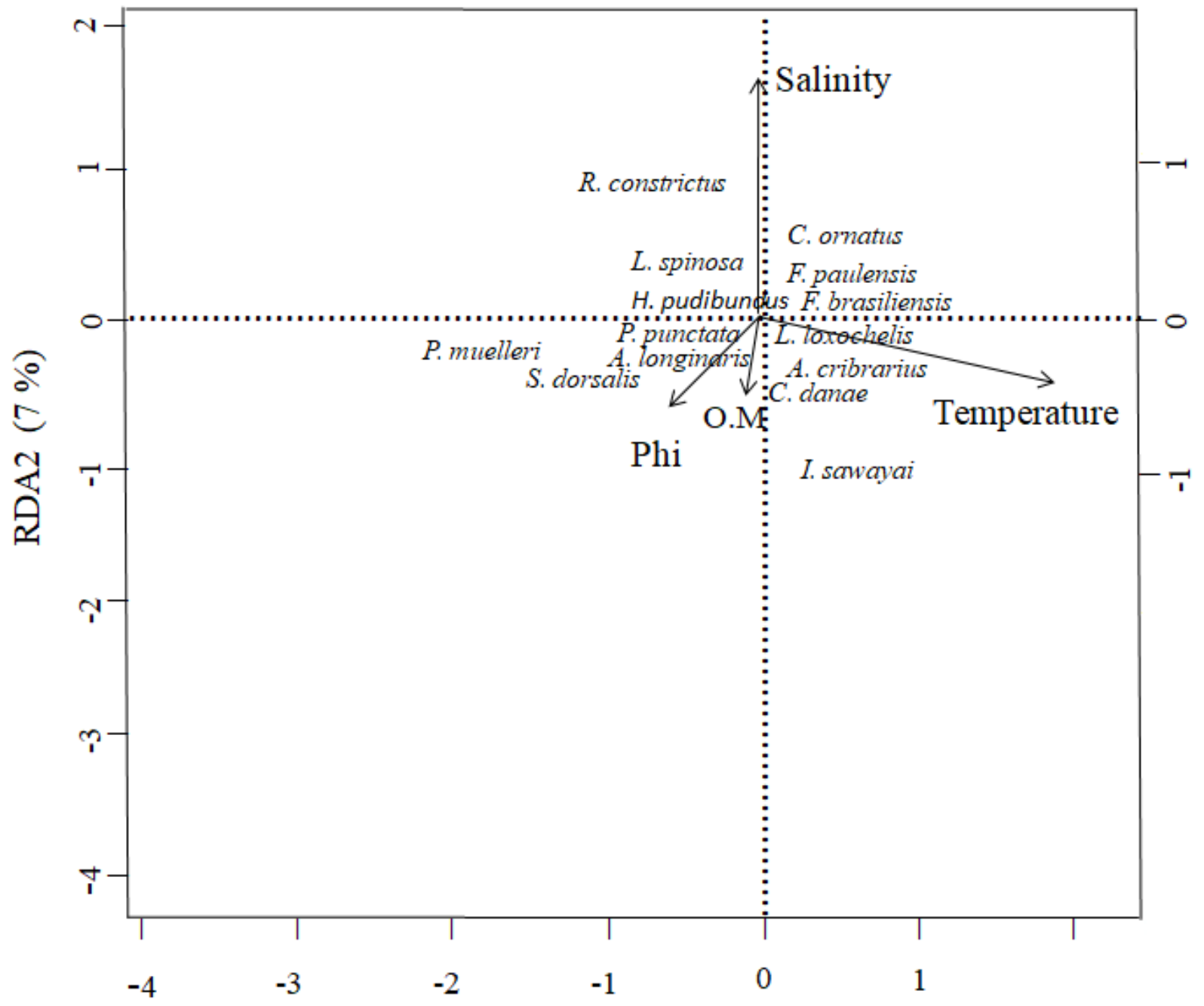

RDA1 (19\%)

Figure 5. Biplot of the axes from the Redundancy Analysis (RDA). Spatial variation of the biological and environmental variables from July 2010 through June 2011 in the adjacent area from Babitonga Bay, SC. Arrows indicate the strength of the relation between the axes and the environmental factors (O.M= Organic matter content; Phi=Substrate granulometry). 


\section{DIsCUSSION}

The results presented in this study indicate that the studied environment (which is within a subtropical region) hosts several decapod crustacean species. Remarkably, this region exhibited the same species richness as that observed by Costa et al. (2016) in Macaé (RJ). Otherwise, our results have lower richness than studies made in the northern coast of São Paulo state with 41 and 44 species according to SeverinoRodrigues et al. (2002) and Fransozo et al. (2016), respectively. The northern coast of São Paulo state has a subtropical/tropical transitional marine fauna including species from different regions (Sumida and Pires-Vanin, 1997; Boschi, 2000).

In general, subtropical regions exhibit lower species richness than tropical regions, since in these habitats the environmental features present a higher range of seasonal variation (Thorson, 1950; Gray, 2007). Furthermore, the studied area should be considered of ecological importance because of its high species richness relative to other nearby tropical areas, such as Matinhos (Paraná State), where Lunardon-Branco and Branco (1993) found 11 decapod crustacean species, and the Armação do Itapocoroy (Santa Catarina State), in which Fracasso and Branco (2000) found 20 species.

Additionally, the presence of a considerable number of species classified as Co makes this region highly ecologically important. These data suggest that this heterogeneous environment provides a variety of microhabitats and corresponding environmental complexity (Garcia et al., 2018). Thus, fishing activities in this region may present a risk to the local fauna, either from bycatch or from the seafloor alterations that the trawling fleet may cause (Pilskaln et al., 1998; Beserra da Silva Júnior et al., 2015).

Trawling fisheries might also impact the accessory and accidentally collected species, primarily because these species have higher occurrences in the spring and summer, which are seasons known for having high primary productivity (Stanski et al., 2018). Marine decapod crustaceans exhibit migratory tendencies toward regions with higher food availability in order to reproduce, since, during their early developmental stages, the offspring will find abundant food resources to grow and develop properly. Therefore, even though they have been considered accessories, such species are likely captured as bycatch during their reproductive periods, potentially limiting the persistence of their populations in this area.

Among the accidentally captured species, I. sawayai reproduces in the studied area (Stanski and Castilho, 2016). Therefore, even though this capturing is considered accidental, the persistence of the species may be threatened, since trawling captures individuals in its reproductive period. In cases such as this, the long-term consequences may be severe (Foster and Vincent, 2010).

The organic and inorganic material existent at trawling sites is another serious issue in coastal areas. Such materials are an aggravating factor because they contribute to the coverage of net meshes, reducing their selectivity. This might lead to higher captures of juvenile animals, which are frequently migrating to the offshore region to complete their life cycle, as exemplified by pink shrimp (Farfantepenaeus spp.) and white shrimp (Litopenaeus spp.), for instance, as well as for the swimming crabs Callinectes spp.

The high representation of the Portunidae family (three out of four species were classified as Co and $\mathrm{Va}$ ) may be related to their preference for shallow water areas with a sandy or muddy bottom (Melo, 1999b). Callinectes danae was the most abundant species followed by C. ornatus, probably due to these species' tolerance to lower salinity values and their ability to adjustment to temperature changes, thus providing the ability to occupy estuarine areas (Baptista-Metri et al., 2005). Since the studied region is influenced by a substantial freshwater inflow (Stanski and Castilho, 2016), species that are adapted to salinity and temperature variations typically perform well here. Callinectes danae is an intensely exploited fishing resource, mainly in bay areas, acting as a food supplementation and, consequently, an economic complement to many families living in coastal communities (Baptista-Metri et al., 2005).

Arenaeus cribrarius occurrence was classified as Co and Va, though this species can withstand a wide thermal range (from 11.0 to $30.8^{\circ} \mathrm{C}$ ) (Ávila and Branco, 1996; Pinheiro and Fransozo, 2002). The highest abundances we found were associated with warmer temperatures, which may be related to its preferred optimum temperature. This species is observed in considerable abundance along the Brazilian coast and may offer considerable economic potential associated with shrimp fishing (Fransozo et al., 1992). However, it is still considered a fishing "reject" (Pinheiro and Fransozo, 2002). 
Considering the Penaeoidea species, $P$. muelleri had the highest abundance (71\%), thus being classified as Va. In the last decade, in light of diminishing catches of species of higher economic importance, P. muelleri has become an economically attractive species in southern and southeastern Brazil (Carvalho-Batista et al., 2011). However, together with $A$. longinaris, we classified $P$. muelleri as an accessory species, which may reflect their adaptations to stable water temperature; i.e., since we captured both species in periods of the year when water temperature was cold, they may be considered as cold-water indicators (Costa et al., 2005; Castilho et al., 2008). P. muelleri is commonly found in great abundances in cold water areas in Argentina and, because of this, is an important fishing resource in that country (Boschi, 1989). We also captured $R$. constrictus, which was classified as Ab but has little economic value because of its small size (Costa and Fransozo, 2004).

In our study, the crustacean bycatch was remarkable more for its species diversity than for its biomass. Unlike the majority of bycatch studies, in which the crustacean bycatch biomass is greater than that of the target species (Alverson et al., 1994; Branco and Verani, 2006; Sedrez et al., 2013; Costa et al., 2016), we detected the opposite, with an average $X$. kroyeri catch considerably greater than the remaining crustacean species, arriving only in November and December a relationship near of $1: 1$, periods with high rainfall indexes (Stanski et al., 2016). It is proposed that variation of water temperature and organic matter increase caused an increase in the abundance of species, mainly for reproduction, such as I. sawayai as found by Stanski and Castilho (2016).

However, it is important to remember that we focused our analysis on decapod crustaceans. As mentioned before, other taxa can also occur in the seabob shrimp fishery bycatch, which would increase both bycatch biomass and species richness. If such organisms are considered, the amount of rejected bycatch could reach approximately $50 \%$ of the total catch, which is a high and worrisome proportion (Graça-Lopes et al., 2002a). Nevertheless, the high proportion of $X$. kroyeri in our study might be because this is a dominant organism in the benthic communities along the Brazilian coast (Graça-Lopes et al., 2002b).

We observed that the studied area has high decapod species richness, including many resident species, as well as others that likely reach this area during reproductive periods, leading to considerable increases in the crustacean fauna.

Therefore, our findings support the importance of considering the impact that marine invertebrate populations sustain during shrimp fishing activities. Additionally, our data reinforce the need for applying legal measures in order to preserve species that are continuously captured by the fishing fleet, such as $P$. muelleri, I. sawayai and C. danae, which have higher abundances during periods outside of the Brazilian fisheries closure period, measures as areas of permanent conservation distributed along the coast to serve as refuge for the species.

\section{ACKNOWLEDGMENTS}

The authors are indebted to foundations that provided financial support during field collections: Fundação de Amparo à Pesquisa do Estado de São Paulo - FAPESP (Temático Biota 2010/50188-8), Coordenação de Aperfeiçoamento de Nível Superior CAPES - Ciências do Mar II (23038.004310/2014-85 and 2005/2014 — 23038.004308/2014-14), Fundação para o Desenvolvimento da Unesp - FUNDUNESP (1214/2010 - DFP), and Pró Reitoria de Pesquisa da Unesp (PROPE).

\section{References}

Alverson, D.L.; Freeberg, M.H.; Pope, J.G. and Murawski, S.A. 1994. A global assessment of fisheries bycatch and discards. FAO Fisheries \& Aquaculture - Technical Papers, 339: 13-233.

Ávila, M.G. and Branco, J.O. 1996. Bioecological aspects of Arenaeus cribrarius (Lamarck) (Decapoda, Portunidae) from Praia da Barra da Lagoa, Florianópolis, Santa Catarina, Brazil. Revista brasileira de Zoologia, 13: 165-174.

Bail, G.C. and Branco, J.O. 2007. Artisanal Fishery of sea-bobshrimp: a socioeconomic characterization in the Penha, SC. Brazilian Journal of Aquatic Science and Technology, 11:25-32.

Bertini, G.; Fransozo, A.F. and Melo, G.A.S. 2004. Biodiversity of brachyuran crabs (Crustacea: Decapoda) from nonconsolidated sublittoral bottom on the northern coast of São Paulo State, Brazil. Biodiversity Conservation, 13: 2185-2207.

Baptista-Metri, C.; Pinheiro, M.A.A.; Blankensteyn, A. and Borzone, C.A. 2005. Populational and reproductive biology of Callinectes danae Smith, 1869 (Crustacea, Portunidae) in Shangri-lá Beach, Pontal do Paraná, Brazil. Revista brasileira de Zoologia, 22: 446-453.

Beserra da Silva Júnior, C.A.; Viana, A.P.; Frédou, F.L. and Fredou, T. 2015. Aspects of the reproductive biology and characterization of Sciaenidae captured as bycatch in the prawn trawling in the northeastern Brazil. Acta Scientiarum Biological Sciences, 37:1-8. 
Boschi, E.E. 1989. Fishery biology from the shrimp of the Patagonian coast of Argentina (Pleoticus muelleri). National Fisheries Research and Development, 646: 5-71.

Boschi, E.E. 2000. Species of decapod crustaceans and their distribution in the American marine zoogeographic provinces. Revista de Investigación y Desarrollo Pesquero, 13:7-136.

Branco, J.O. and Verani, J.R. 2006. Quali-quantitative analysis of sea-bob-shrimp's ichthyofauna bycatch, at Armação do Itapocoroy, Penha, Santa Catarina. Revista brasileira de Zoologia, 23: 381-391.

Carvalho-Batista, A.; Simões, S.M.; Lopes, M. and Costa, R.C. 2011. Ecological distribution of the shrimp Pleoticus muelleri (Bate, 1888) and Artemesia longinaris Bate, 1888 (Decapoda: Penaeoidea) in the Southeastern Brazilian littoral. Nauplius, 19: 135-143.

Castilho, A.L.; Pie, M.R.; Fransozo, A., Pinheiro, A.P. and Costa, R.C. 2008. The relationship between environmental variation and species abundance in shrimp community (Crustacea: Decapoda: Penaeoidea) in south-eastern Brazil. Journal of the Marine Biological Association of the United Kingdom, 88: 119-123.

Coelho, J.A.P.; Puzzi, A.; Graça-Lopes, R.; Rodrigues, E.S.; and Prieto Jr., O. 1986. Analysis of fish rejection in artisanal fisheries directed at sea-bob shrimp (Xiphopenaeus kroyeri) on the coast of São Paulo. Boletim do Instituto de Pesca, 13: 51-61.

Costa, R.C.; Fransozo, A.; Melo, G.A.S. and Freire, F.A.M. 2003. An illustrated key for Dendrobranchiata shrimps from the northern coast of São Paulo state, Brazil. Biota Neotropica, 3: $1-12$.

Costa, R.C. and Fransozo, A. 2004. Abundance and ecologic distribution of the shrimp Rimapenaeus constrictus (Crustacea: Penaeidae) on the northern coast of São Paulo State, Brazil. Journal of Natural History, 38: 901-912.

Costa, R.C.; Fransozo, A.; Castilho, A.L. and Freire, F.A.M. 2005. Annual, seasonal and spatial variation of abundance of the shrimp Artemesia longinaris (Decapoda: Penaeoidea) in southeastern Brazil. Journal of the Marine Biological Association of the United Kingdom, 85: 107-112.

Costa, I.D. and Di Beneditto, A.P.M. 2009. Caracterización preliminary de los invertebrados bentónicos capturados accidentalmente em la pesca de camarones en el Norte del estado de Río de Janeiro, Sudeste de Brasil. Latin American Journal of Aquatic Research, 37: 259-264.

Costa, R.C.; Carvalho-Batista, A.; Herrera, D.R.; Pantaleão, J.A.F.; Teodoro, S.S.A. and Davanso, T.M. 2016. Carcinofauna acompanhante da pesca do camarão-sete-barbas Xiphopenaeus kroyeri em Macaé, Rio de Janeiro, sudeste brasileiro. Boletim do Instituto de Pesca, 42: 611-624.

Dajoz, R. 1983. Ecologia Geral. São Paulo, Editora Vozes, EDUSP, $472 \mathrm{p}$.

D’Incao, F.; Valentini, H. and Rodrigues, L.F. 2002. Assessment of the shrimp fishery at Southern and South Brazil. Atlântica, 24: 49-62.

Fantucci, M.Z.; Biagi, R.; Meireles, A.L. and Mantelatto, F.L. 2009. Influence of biological and environmental factors on the spatial and temporal distribution of the hermit crab Isocheles sawayai Forest \& Saint-Laurent, 1968 (Anomura, Diogenidae). Nauplius, 17: 37-47.
Foster, S. and Vincent, A. 2010. Tropical shrimp trawl fisheries: Fishers' knowledge of and attitudes about a doomed fishery. Marine Policy, 34: 437-46.

Fracasso, H.A.A. and Branco, J.O. 2000. Bycatch from the seabob shrimp (Xiphopenaues kroyeri) fishery in the Armação de Itapocoroy, Penha. p. 565-567. In: Semana Nacional de Oceanografia, Resumos Expandidos. Itajaí, Universidade do Vale do Itajaí..

Franco, A.C.N.P.; Schwarz Junior, R.; Pierri, N. and Santos, G.C. 2009. Levantamento, sistematização e análise da legislação aplicada ao defeso da pesca de camarões para as regiões sudeste e sul do Brasil. Boletim do Instituto de Pesca, 35: 687-699.

Fransozo, A.; Negreiros-Fransozo, M.L. and Mantelatto, F.L.M. 1992. Composition and distribution of Brachyura (Crustacea, Decapoda) from the sublittoral sediments in Fortaleza Bay, Ubatuba, SP. Revista Brasileira de Biologia, 52: 667-75.

Fransozo, A.; Sousa, A.N.; Rodrigues, G.F.B.; Telles, J.N.T.; Fransozo, V. and Negreiros-Fransozo, M.L. 2016. Crustáceos decápodes capturados na pesca do camarão-sete barbas no sublitoral não consolidado do litoral norte do estado de São Paulo, Brasil. Boletim do Instituto de Pesca, 42: 369-386.

Garcia, J.R.; Lopes, A.E.B.; Silvestre, A.K.C; Grabowski, R.C.; Barioto, J.G.; Costa, R.C. and Castilho, A.L. 2018. Environmental characterization of the Cananéia coastal area and its associated estuarine system (São Paulo state, Brazil): Considerations for three Penaeoidean shrimp species. Regional Studies in Marine Science, 19: 9-16.

Grabowski, R.C.; Simoes, S.M. and Castilho, A.L. 2014. Population structure, sex ratio and growth of the seabob shrimp Xiphopenaeus kroyeri (Decapoda, Penaeidae) from coastal waters of southern Brazil. ZooKeys, 457: 253-269.

Graça-Lopes, R.; Tomás, A.R.G.; Tutui, S.L.S.; SeverinoRodrigues, E. and Puzzi, A. 1993a. Fauna acompanhante da pesca camaroeira no litoral do estado de São Paulo, Brasil. Boletim do Instituto de Pesca, 28: 173-188.

Graça-Lopes, R.; Rodrigues, E.S.; Puzzi, A.; Pita, B.; Coelho, J.A.P. and Freitas, M.L. 1993b. Ichthyologic survey in the Santos Bay, São Paulo State, Brazil. Boletim do Instituto de Pesca, 20: 7-20.

Graça-Lopes, R.; Tomás, A.R.G.; Tutui, S.L.S.; SeverinoRodrigues, E. and Puzzi, A. 2002a. The shrimp fishery bycatch of the São Paulo State coast, Brazill. Boletim do Instituto de Pesca, 28: 173-188.

Graça-Lopes, R.; Puzzi, A.; Severino-Rodrigues, E.; Bartolotto, A.S.; Guerra, D.S.F. and Figueiredo. K.T.B. 2002b. Comparison between by-catch and shrimp production landings by the small shrimp trawlers in Perequê beach, São Paulo State, Brazil. Boletim do Instituto de Pesca, 28: 189-194.

Gray, J.S. 2007. Marine biodiversity: patterns, threats and conservation needs. Biodiversity Conservantion, 6: 153-175.

Håkanson, L. and Jansson, M. 1988. Principles of lake sedimentology. Berlin, New York, Springer-Verlag, 798p.

Lunardon-Branco, M.J. and Branco, J.O. 1993. Brachyura bycatch of Menticirrhus littoralis (Holbrook, 1860), in Matinhos and Caiobá region, Paraná coast, Brazil. Brazilian Archives of Biology and Technology, 36: 479-487. 
Mantelatto, F.L.; Martinelli, J.M. and Fransozo, A. 2004. Temporal-spatial distribution of the hermit crab Loxopagurus loxochelis (Decapoda, Anomura, Diogenidae) from Ubatuba Bay, São Paulo State, Brazil. Revista de Biologia Tropical, 52: 47-55.

Melo, G.A.S. 1996. Manual de identificação dos Brachyura (caranguejos, siris) do litoral brasileiro. São Paulo, Plêiade, 604p.

Melo, G.A.S. 1999a. Manual de identificação dos crustacea Decapoda do litoral brasileiro: Anomura, Thalassinidea, Palinuridea e Astacidea. São Paulo, Plêiade, 551p.

Melo, G.A.S. 1999b. Infraorder Brachyura. Siris and crabs. Marine and estuarine species. p. 415-485. In: L. Buckup and G. BondBuckup (eds), Os crustáceos do Rio Grande do Sul. Porto Alegre, Editora UFRGS.

Murray, J.D.; Bahen, J.J. and Rulifson, R.A. 1992. Management considerations for by-catch in the North Carolina and Southeast Shrimp Fishery. Fisheries, 17: 21-26.

Pilskaln, C.H.; Churchill, J.H. and Mayer, L.M. 1998. Resuspension of sediment by bottom trawling in the Gulf of Maine and potential geochemical consequences. Conservation Biology, 12: 1223-1229.

Pinheiro, M.A.A. and Fransozo, A. 2002. Reproduction of the speckled swimming crab Arenaeus cribrarius (Brachyura: Portunidae) on the Brazilian coast near 2330'S. Journal of Crustacean Biology, 22: 416-428.

Pezzuto, P.R.; Alvarez, P.J.A. and Wahrlich, R. 2006. Deep-sea shrimps (Decapoda: Aristeidae): new targets of the deep-water trawling fishery in Brazil. Brazilian Journal of Oceanography, 54: 123-134.

Rodrigues, A.M.T.; Branco, E.J.; Pereira, M.T.; Zimmermann, C.E.; Ribeiro, G.C.; Branco, J.O.; Kuroshima, K.N.; Clezar, L.; Brutto, L.F.; Cremer, M.J.; Souza Filho, M.A.C.; Hostim Silva, M.; Tognella, M.M.P.; Alves, S. and Bellotto, V. 1998. Proteção e Controle de Ecossistemas Costeiros: Manguezal da Baía de Babitonga, Itajaí (SC). Coleção Meio Ambiente. Série Estudos-Pesca, No. 25. Brasília, 145p.

Rodrigues-Filho, J.L.; Couto, E.C.G.; Barbieri, E. and Branco, J.O. 2016. Ciclos sazonais da carcinofauna capturada na pesca do camarão-sete-barbas, Xiphopenaeus kroyeri no litoral de Santa Catarina. Boletim do Instituto de Pesca, 42: 648-661.

RDevelopment Core Team. 2009. R: A language and environment for statistical computing. R Foundation for Statistical Computing, Vienna, Austria. ISBN 3-900051-07-0. Available at http:/ /www.R-project.org. Access on 25 May 2018.
Sedrez, M.C.; Branco, J.O.; Freitas-Junior, F.; Monteiro, H.S. and Barbireri, E. 2013. Ichthyofauna bycatch of sea-bob shrimp (Xiphopenaeus kroyeri) fishing in the town of Porto Belo, SC, Brazil. Biota Neotropica, 13: 165-175.

Severino-Rodrigues, E.; Guerra, D.S. and Graça-Lopes, R. 2002 Carcinofauna acompanhante da pesca dirigida ao camarão sete-barbas (Xiphopenaeus kroyeri) desembarcada na Praia do Perequê, Estado de São Paulo, Brasil. Boletim do Instituto de Pesca, 28: 33-48.

Sousa, R.; J. Delgado; Pinto, A.R.; Biscoito, L.; Carvalho, D. and Henriques, P. 2017. Prospective study of the fishery of the shrimp Plesionika narval (Fabricius, 1787) in the Northeastern Atlantic. Brazilian Journal Biology, 77: 585-593.

Suguio, K. 1973. Introdução a sedimentologia. São Paulo, Edgard Blucher, 450p.

Sumida, P.Y.G. and Pires-Vanin, A.M.S. 1997. Benthic Associations of the shelf brake and upper slope off Ubatuba-SP, southeastern Brazil. Estuarine, Coastal and Shelf Science, 44: 779-784.

Stanski, G. and Castilho, A.L. 2016. Reproductive biology of the hermit crab Isocheles sawayai (Crustacea, Anomura) from coastal waters of Southern Brazil. Invertebrate Reproduction \& Development, 60: 103-111.

Stanski, G; Mantelatto, F.M. and Castilho, A.L. 2016. Hermit crab bycatch fauna (Decapoda, Anomura) off the coast of Santa Catarina State, Brazil: diversity and spatial-temporal distribution. Hermit crab bycatch fauna in Santa Catarina State, Brazil. Latin American Journal of Aquatic Research, 44: 546-556.

Stanski, G.; Carvalho, M.M.; Garcia, J.G.; Goncalves, G.R.L.; Costa, R.C. and Castilho, A.L. 2018. Geographical variation and local environment effects in the reproductive output and fecundity of the shrimp Exhippolysmata oplophoroides (Decapoda: Caridea) in southeastern Brazil. Invertebrate Reproduction \& Development, 62: 119-124.

Thorson, G. 1950. Reproductive and larval ecology of marine invertebrates. Biological reviews of the Cambridge Philosophical Society, 25: 1-45.

Tucker, M. (ed). 1988. Techniques in sedimentology. Oxford, Boston, Blackwell Scientific Publications, 241p.

Wilson, K. and Hardy, I.C.W. 2002. Statistical analysis of sex ratios: an introduction. p. 48-92. In: I.C.W. Hardy (ed), Sex Ratios: Concepts and Research Methods. Cambridge, Cambridge University Press.

Zar, J.H. 1999. Biostatistical analysis. Fourth edition. Upper Saddle River Prentice Hall, 560p. 